\title{
ROYAL MORALITIES AS REVEALED IN THE PAGES OF AGNI PURĀNA AND ITS RELEVANCE IN THE PRESENT DAY SOCIETY
}

\author{
Dr. Amborish Adhyapok
}

\begin{abstract}
The Agnipurāna occupies a prominent place among all the Purānas for the vast areas of knowledge it deals with. The ethical teachings revealed in its description of good governance bear a lot of importance since these have relevance for all times. In this paper a discussion is sought to be presented on the ethics and royal duties as Agnipurāna delineates keeping in mind the corrupted, demoralized scenery of today's degraded society
\end{abstract}

From the point of view of diversity of subjects and of plentiful treasury of worldly as well as spiritual knowledges, Agnipurāna has occupied an important place in Purānic literature. For innumerable topics Agnipurāna deals with like Social science, Politics, Mimāninsā, Ethical science, Astronomy, Astrology, Medical science, Vedic teachings, Metres, Grammar, Vedānga literature, different lessons of Ramāyaña and of Mahābhārata, characteristics of ideal states, cities, houses and living grounds, funeral customs, different types of worship of the god, description about the creation of the universe, description about different sacred activities and glory of divine places etc. and many other important topics for which it can be termed to be an adequate hand-book on the path of journey of life for human beings. Here, keeping in mind the corrupted, demoralised scenery of today's degraded society a discussion is sought to be presented on ethics and royal duties as well as moralities as Agnipurāna delineates. In Agnipurāna chapter 238 and 239 are devoted wholly on the dscriptions of ethics and royal duties. These two chapters are named as Rāmokta-nïti' and 'Rājadharma-kathana' respectively. 
Agnipurāna is called so because, the teachings of this Purāna are first sprung from the mouth of Lord Agni towards sage Vaśișțha, then from Vaśișțha towards Vedavyāsa, then from Vedavyāsa towards three sages Suka, Suta and Paila and finally from Suta to the latter sages Śaunaka etc. In Agnipurāna four chief duties called Rājavrtta are mentioned as professed by sage Puṣkara. These are latter advised towards Laxmana by his elder brother Ramachandra which are said to have enriched with religious merits and to have offered victory over enemies. ${ }^{1}$ The four Rājavrtttas are - earning of wealth through proper way, enrichment of wealth, its protection and charity over adequate person. ${ }^{2}$ It is rightly said here that a king should rule over his state first being a polite man, and for the attainment of that good quality he is instructed to be the dominant one over his senses. Victory over senses is said here to be the way that makes a king moral one. Here in this Purāna, sense organs are compared to an intoxicated elephant that runs straight towards the forest of earthly objects being perturbed by the unsteady mind. Those sense organs are to be controlled by the strings of knowledge as the elephant-driver controls the inebriated elephant with the help of an ankus. ${ }^{3}$ Rāma states Laxmana that according to the teachings of sage Puṣkara, there are six Vargas i.e. six human enemies viz., carnal desire or lust (kāma), wrath (krodha), self consciousness about one's own weight or his dignity (māna), covetousness (lobha), cheerfulness (harșa) and pride (mada). As has been said in this Purāna, there is no probability of peace if these six qualities cannot be forsaken or warded off by the people on earth. ${ }^{4}$

Sage Puskara speaks about 18 human qualities which are to be attained by a man in order to be a perfect and ethical one. Those 18 qualities are- knowledge of holy scriptures (śāstra-jñāna), intellect (prajñâ), patience (dhṛtih), skill (dārkșyam), audacity (prāgalbhyam), zeal or enthusiasm (utsāham), speech-restraint (vāgmitâ), generosity (audāryam), patience in emergent condition (āpatkāla-sahișnutā), true power (prabhāvam), purity (śucitā), friendliness (maitrî), munificence (tyāgah), truthfulness (satyam), gratefulness (krtajñatâ), race(kulam), well-behaviour (śîlam), and the power of subjugation (damah). ${ }^{5}$ These 18 qualities are said firmly to be the causes of the attainment of wealths and prosperity 
in this Purāna. In Agnipurāna an advice on the four main parts of Royal science viz., $\bar{A} n v \bar{i} k s \underline{i k} \bar{i}$, Trayī, Vārtā and Daṇdanīti are seen to be given. Ánviksșiki means Logical science, Trayi is the knowledge of the Vedas, Vārtā means occupation and livelihood, and Dandaniti is the science that deals with the Laws of punishments.

A good lesson on common ethics is seen to be offered in Agnipuraña towards the people on earth observing which a man can enhance his personality to the position of a high-level mind and soul. Firstly it is said that non-violence, true speech, purity, kindness and forgiveness - these are people's general nature and should be shown among others. ${ }^{6}$ One should proceed towards the welfare of others, he should always try to speak the truth and favourable speeches. It is interesting to note that protection to the weak people and to the refugees by the powerful one is given more important place here. The noble man bears this quality as his vow indeed. Agnipurāṇa says:

\section{vāk sunṛtā dayā dānam̉ hīnopagatarakṣaṇam/ /}

iti vṛttami satām sādhuhitam satpuruṣavratam $/{ }^{7}$

All are mortal. Nothing is permanent in this world. One day everything will be devastated, and will go to the mouth of death. So, Agnipuranna urges the rulers not to give pains to his subjects specifically to the common people and not to keep their foot steps in the paths of irreligious, illegal matters. The rulers are advised here to first welcome all people with amiable voice in the same way, whichever quality he or she bears - good or bad, noble or cruel and so on. ${ }^{8}$ To say clearly, Agnipurāna gives special importance in the deliverance of pleasing words toward others. Agnipuraña gives stress towards the matter of deliverance of pleasant words in such a remarkable way that depending upon that very quality it defines the natures of deity and of animals. According to this Purāna, the difference between deity and animal is that, deity speaks the pleasing words and animals speak the harmful:

\section{devāste priyavaktāraḥ paśavaḥ krūravādinaḥ ${ }^{9}$}

That means he is god who is sweet -speaker and he is animal who throws the cruel, pitiless words towards others. Hard-hearted are 
titled here as animals thereby urging people to attain the quality of humanity.

What kind of services should be offered to the people of different positions and to the god also, Agnipurāna gives a lesson on this matter. According to this Puranna, preceptors should be served by reverential prostration, noble persons through true behaviour, deities are by sacred and devotional deeds, women as well as servants through love and charity, and the beggers should be served through adequate alms. ${ }^{10}$ In respect of the matter of good conduct Agnipurāna preaches about 15 noble qualities, those are as follows: ${ }^{11} 1$ ) not censuring other's activities, 2) observing one's own duties accurately, 3) sympathy towards the misers, 4) application of pleasing words everywhere, 5) offering help towards the true friends by means of even his own life too, 6) offering shelter to the guests coming to the house, 7) charity according one's own ability, 8) endurance, 9) free from arrogance on self prosperity, 10) happiness or free from jealousy on other's improvement, 11) keeping himself away from delivering speech which can hurt other's minds, 12) practice of taciturnity, 13) firm connection amid the friends, 14) good binding with the relatives, and 15) practice of accomplishing the works which should be done.

In the next chapter i.e. chapter 383, there is a good lesson professed by sage Pușkara, wherein everything relating to the picture of an ideal state is found to be discussed, such as limbs of state, nature of a good ruler, characteristics of royal secretaries, nature of royal preceptor, description of the nature of lands suitable for a state, methods of building the royal forts, skills of their protection, what kind of qualities the servants of a king should sustain, what kind of people should be appointed in the seats of ministry, nature of state's army, nature of treasury, nature of royal friends etc. and many others which can be termed to be the platform in respect of making a great role towards the political sceneries of modern time.

Rāma declares about 7 limbs of a kingdom which are called Rajjyānga, viz. , the king, ministers, royal friends, treasury, force, fort and the state. ${ }^{12}$ Of these 7 limbs, the $7^{\text {th }}$ i.e. the state is the most important and the king should try to protect it anytime by any 
means. As has been said in Agnipurāna, an adequate king should be the bearer of some specific qualities, such as, belonging to a high dynasty, well-behaviour, proper age, virtuousness, service-oriented towards the old, charity, rapidity in action, indisputability, arduousness, truthfulness, gratefulness, spirituality, intellect, chastity, gross-looking, mildness, righteousness, fondness on life in a big family, firm devotion, corroboration and far vision. ${ }^{13} \mathrm{He}$ should always try to maintain good relation with the neighbouring rulers.

In this Purāna it is said that, that person should be appointed in the post of chief manager of the king who belongs to a good, ideal family; who is free from cruelty and who is always pure by character, heart and mind. ${ }^{14}$ Here in this Purāna sage Puṣara declares about some heavenly qualities observing which a king can uplift his position to a deity-like king. These qualities are termed as $\bar{A}$ tmasampadguna ${ }^{15}$ i.e. 'qualities that a man is adorned by like ornaments', viz., dexterity in speech, bravery, quality of good recollection, patience, physical energy, power of domination, knowledge about the codes of punishments, leading power, adroitness, interest on the occupations of manual or mechanical arts, retentive endurance in other's complains, watchfulness towards all kinds of other's activities, knowledge about Sandhi (alliance), Vigraha (battle), and Tattva (reality); knowledge regarding various conditions of secret counsels; knowledge about sate, time and partitions; ability of earning money and wealth properly; proper application of money; knowledge of those to whom charity is done; free from anger, mischief and covetousness; free from diabolism, envy, malice and jealousy; steadiness; truthfulness; submissiveness on old's advice; mild behaviour and interest in other's merits.

The Agnipuranna states that the royal ministers should be of a high family by nature. He is to be appointed in the chair of ministry who is clear and pure by heart and mind, who is valiant, familiar to the knowledge of holy scriptures, impassioned and is expert in the field of the judgment of punishments and rewards. ${ }^{16}$ Among the ministers, one should be appointed in the chair of chief minister or the secretary. The Puranna states that the secretary should be eloquent i.e. skilled in language, heroic, well-visioned, arduous, 
wealthy, unobstructed, steady and friendly in behavior. He should possess the quality of endurance in painful situations and the quality of purity. The secretary should be truthful, virtuous, firmminded, powerful and healthy too. He has to be the possessor of some other qualities too, those are - intelligence, dexterity in any matter, tranquility by mind, firm devotion towards the kingdom and the ability of destroying any kind of hostility. ${ }^{17}$ Agnipurāna asserts some specific qualities in this regard which are termed as Mantri-sampad, ${ }^{18}$ i.e. 'wealth of ministry', viz., power of memory, consciousness towards the proper application of money and wealth, ability of comprehending other's mind, firm determination towards the accomplishment of their activities, proficiency in knowledge, perseverance and the nature of concealing private counsels. ${ }^{19}$

Description about the nature of a royal priest is found to be seen remarkably in Agnipurāna. According to this Purāna, the priest should attain the knowledge of Trayi i.e. of the Vedas, He should be skilled enough, in ethics and should be expert in the Atharvavedic customs on peace and prosperity. ${ }^{20}$ An interesting fact is to be noticed here in this connection that, in this Puranna there is a beautiful description about the process of examining the nature of the members which are to be appointed in the chairs of ministry. It is said that the skilfulness and artistic minds of the ministers should be examined by those people who are expert in the concerned matters. The king should collect information from the neighbours about their race, place, habitual activities, dexterity on different works, knowledge, bravery and generosity. Through various types of conversations their eloquence and truthfulness are said to be examined. And, during the time of calamities their zeal, power, arduousness, patience, devotion and firm-mind should be watched. Their favourable mind and cleanliness are said to be examined through their amiable behaviours. There it is said that through co-habitation the examiners, appointed by the king, should observe the ministers' vigour, health, steadiness, character and the nature free from proclaiming of enmity. And, through visible or direct interview their courtesy or politeness and meanness are said to be examined. ${ }^{21}$ 
The Agnipurāna also provides description of the land which is fit for a state or a kingdom. It is said that an ideal territory should be adorned with good cultivation, minerals, plentiful drinking water, various holy places and good land and water ways. ${ }^{22}$ It should be fair in vision, advantageous for the cows and should be connected with the force of elephants. That very land is prescribed by sage Puskara to be the fittest one for kingdom wherein there is the availability of workers, artists, traders and abundant cultivation, where customs of various noble activities are performed frequently, where there is the endurance on diseases, where there is the habitation of foreign people, there is the existence of religion and where there are animals, force and the scholars. ${ }^{23}$ There it is said that the boundary of a territory should be vast and extensive one. It should have estates of large extent, elevated entry-doors and big apartments. The ideal kingdom should be connected with hills, mountains, rivers, forests and with the deserts too. ${ }^{24}$

In the context of royal description Agnipurāna throws a light on the nature of forts, treasury and of the army, as, these are the most essential parts of a good-governed territory. According to this Purāna, six types of forts are the most necessary for a state to be safe, and those are namely - Audaka (water -fort), Pārvata(hillfort), Vārkșa (forest-fort), Airiṇa (desert-fort), Dhānvan (land-fort) and Mahat (high pillar-fort):

\section{jalavandhānyaghanavaddurgaṁ kālasahami mahat/ audakaṁ pārvvatami vārkșamairiṇami dhanvinañca șaț///25}

With regard to the nature of royal treasury Agnipurāna says that it should be filled with desired objects. Ideal treasury is to be maintained according to the good rules once formed by the predecessors, to be raised through proper and holy ways and to be oriented to proper expenditure. ${ }^{26}$ Such kind of treasury helps a state to move in onward journey towards the increasement of dharma i.e. religious merits. Regarding the nature of ideal army Agnipuranna says that the army-force should be controlled under the firm laws fixed by the royal forefathers. The state army should be well-united, salaried, well-vigorous, strong, expert in application of different weapons, skilful in various types of battle, highly labourious in all types of war, and purely warriors by caste 
i.e. of the Kșatriya caste. This kind of army is declared to be the adequate for an ideal, safe kingdom. ${ }^{27}$

The Agnipurāna description is found about the nature of royal friends and servants too. What kind of people a king should embrace as his friend, advices four types of friends are mentioned viz., aurasa (family-friend), sannaddha (armoured or impenetrably devoted to ), Vamiśa-kramāgata (friend through dynasty wise) and Asanebhyah Rakșita (protector):

\section{aurasaṁ tatra sannaddham tathā vamísakramāgatam/}

rakșitam vyasanebhyaśca mitram் jñeyam caturvidham//28

A royal friend should be a meditative man. The king should select a person as friend who is favourable-speaker, born in a good family, free from disputes, possessor of high status and dignity and who is helpful. It has been stated in this Purāna, that truthfulness, benignity i.e. the nature of being happy in other's happy moments and sad in other's grief, and deceit less i.e free from evasion are the most essential qualities a royal friend should bear. Regarding the qualities of a royal servant, Agnipurāna says that an adequate servant should be bejeweled by the natures like skillfulness, mildness, firmness, forgivingness, forbearance in pains, satisfaction, morality and zeal. A good servant should forsake some qualities like cruelty, nature of visiting other's habitations, rushness and jealousy etc. A royal servant should always keep himself away from conversations relating to the subjects of battle etc. with dignified persons. He should not expose any matter of his royal master at any condition. A servant also should try to inspire his master in good activities and show his prohibition regarding illegal works. Agnipuranna advises that he should stay always as a faithful servant of his devoted master, but should give up the master with whom he is disappointed. ${ }^{29}$

At the end of the chapter 239, a brief account is given about some duties of an ideal king. It is stated that a king is born for the protection of his subjects. So, his first duty is to give protection to all like that of Parjanya (Vedic god of rain), as, Parjanya showers water to everyone in the same level without any bias. ${ }^{30}$ Here 8 main forces or parts of a state termed as Astavarga, are found to have 
been stated relevantly and the king is advised to maintain these 8 parts properly and very carefully. These 8 parts are -1 ) cultivation, 2) trade-path, 3) fort, 4) national flag and emblem, 5) maintenance of elephants, 6) mines-minerals-sculptures-force, 7) royal income and 8) the work of offering habitations towards the gypsies i.e. the people residenceless. ${ }^{31}$ Thus it is seen from this description that Agnipuranna gives importance towards the lives of mendicants or the gypsies. According to this Puranna, people seem to be afraid of generally in five ways, those are - availability of dresses etc. , theft, relating to the city livelihood, process of becoming affectionate to the king and the king's cupidity. So the king is advised here to collect the royal taxes keeping firmly these five conditions in his mind. The king should protect anyhow the state, his mind and health. He should always keep a step onwards to give protection to his wife and offspring. His duty is to give punishment to the sinners and rewards to the well- doers without any bias and he should not keep belief on his enemies at any condition regarding any matter. ${ }^{32}$

Today's society has been devoured by corruption and profligacy in such a way that the place of morality and honesty seems to have been almost like absent. In today's world regarding every side like social, political, economical, cultural etc. lack of people's righteousness has made remarkably the global society a crooked-shaped. It is worth mentioning here in this context that, lack of dexterity and corrupted activities of the governing bodies of today's many countries have been prohibiting the onward journeys towards proper development of those concerned territories, and have raised themselves as a wall of obstacles in front of those countries' domestic structures, security and foundations of people's ideal lives etc. With respect to this condition, if today's people try a little bit to have a look on the divine, valuable knowledge offered by the Purāna - the great mines of ancient Indian educational civilization, then one can assure that social devastation will definitely be stopped in a broad field and people's character as well as moral qualities will be developed remarkably. It can definitely be said that if the governing bodies of today's society proceed a step to follow at least the ethical teachings as well as the duties and the activities relating to the royal governance, then it is sure that we 
will get a society free from corruption; and will get definitely a clear, well-developed and fully secured territory.

\section{Notes and References:}

1. Cf., nītiste puṣkaroktā tu rāmoktā lakṣmanāya yā/ jayāya tvām pravakṣyāmi śṛnu dharmārdivarddhanīm// Agnipurāna, 238.1

2. Ibid., 238.2

3. Cf., prakīrṇavișayāraṇye dhāvantaṁ vipramāthinam/ jñānānikuśena kurvvīta vaśyamindriyadantinam/ / , ibid.,238.6

4. Cf. kāmaḥ krodhastathā lobho harṣo māno madastathā/ saḍvargamutsrijedenamasministyakte sukhĩ nrpah/ / , ibid.,238.7

5. Ibid., 238.4,5

6. Ibid., 238.10

7. Ibid., 238.11, 12

8. Ibid., 238.15

9. Ibid., 238.16

10. Ibid., $238,17-19$

11. Ibid., 238,19-22

12. Cf. svāmyamātyañca rāștrañca durgam koșo balami suhrd/ parasparopakārīdami saptāngami rājyamucyate //, ibid., 239.1

13. Ibid., 239.2-4

14. Cf., prakhȳatavamiśamakrūram̉ lokasamingāhịnam śucim//, ibid., 239.5

kurvvītātmahitānikṣ̂̄ ca paricāram̉ mahīpatịh/,ibid., 239.6

15. Ibid., 239.6-11

16. Ibid., 239.11,12

17. Ibid., 239.12-15

18. Cf., smṛtistatparatārthesu cittajño jñānaniścayah/ dṛhatā mantraguptiśca mantrismpad prakīrtitā/ / , ibid.,239.15

19. Ibid., $239,16,17$ 
20. Ibid., 239, 17-21

21. Ibid., 239.22

22. Ibid., $239.24,25$

23. Ibid., 239.26.27

24. Ibid., 239.28

25. Ibid., 239.29

26. Ibid., 239.30

27. Ibid., 239.31-33

28. Ibid., $239,36,37$

29. Cf., 239.37-42

30. Cf., àjīivyaḥ sarvvasattvānāin rājā parjanyavadbhabed/, ibid., 239.43

31. Cf., krșivanikpatho durgargam setuh kunjaravandhanam//, ibid., 239.44

khanyākaravalādanam śūnyānānca niveśanam/ aștavargamimai் rājā sādhuvṛtto'nupālayet/ / , ibid.,239.45

32. Cf., daṇ̣̂yāstān daṇụayedrājā svam̉ rakṣecca viṣāditaḥ/ striyah putrānśca śatrubhyo visvasenna kadāsana/ /,ibid.,239.48 